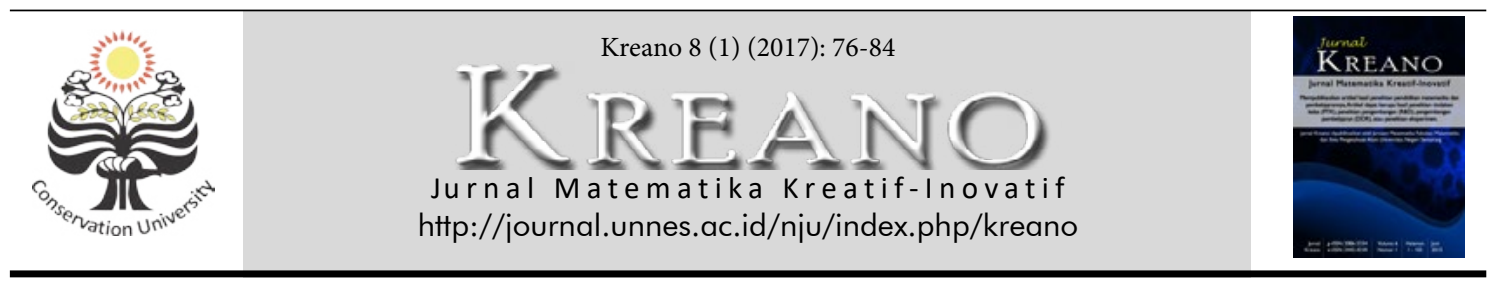

\title{
Pemecahan Masalah Generalisasi Pola Siswa Kelas VII SMP Ditinjau Dari Gaya Kognitif Field Independendt Dan Field Dependent
}

\author{
Septhiana Indra Kusumaningtyas ${ }^{1}$, Dwi Juniati ${ }^{2}$, Agung Lukito ${ }^{3}$ \\ 1,2,3Universitas Negeri Surabaya, Indonesia \\ Email: septhiana.indra@gmail.com
}

DOI: http://dx.doi.org/10.15294/kreano.v8i2.6994

Received : August 2016; Accepted: January 2017; Published: June 2017

\begin{abstract}
Abstrak
Penelitian ini merupakan penelitian deskriptif dengan pendekatan kualitatif yang bertujuan untuk mendeskripsikan pemecahan masalah generalisasi siswa dengan gaya kognitif field independent (SI) dan field dependent (SD). Subjek penelitian adalah 2 siswa kelas VII SMPN 1 Candi yang masing-masing bergaya kognitif FI dan FD. Penelitian dimulai dengan menentukan subjek penelitian menggunakan instrumen GEFT dan TKM, kemudian dilanjutkan dengan pemberian TPM dan wawancara. Pengecekan keabsahan data menggunakan triangulasi waktu. Tugas generalisasi pola melibatkan pola bilangan, gambar, dan masalah kontekstual.
\end{abstract}

\begin{abstract}
This research is a descriptive research with qualitative approach that aims to describe solving problem of generalization of student with cognitive field independent (SI) and field dependent (SD). The subjects of the study were 2 students of class VII of SMPN 1 temple each having cognitive style of FI and FD. Research begins with determining the subject of research using GEFT and TKM instruments, followed by TPM and interviews. We were checking the validity of data using time triangulation. The task of pattern generalization involves patterns of numbers, images, and contextual problems.
\end{abstract}

Keywords: problem solving; pattern generalization; cognitive style; field independent; field dependent

\section{PENDAHULUAN}

Matematika mempelajari pola, baik pola bilangan maupun pola gambar. Pembelajaran matematika tentang pola juga diberikan dari tingkat SD sampai SMA. Pola matematika sederhana dapat dipelajari siswa pada tingkat sekolah dasar misalnya menggunakan bola, blok, atau benda-benda lain yang lebih menarik. Sedangkan anak pada tingkat sekolah yang lebih tinggi dapat melakukan manipulasi pola yang lebih luas dari hanya sekedar mengulang pola.

Tugas generalisasi pola yang diberikan pada siswa merupakan salah satu contoh masalah yang harus diselesaikan siswa. Tugas generalisasi pola dirancang sedemikian hingga siswa diminta menentukan beberapa suku suatu barisan objek sebelum menentukan pola atau aturannya. Materi pola bilangan yang telah dipelajari kelas VII SMP meliputi contoh-contoh pola yang disajikan dengan bentuk visual serta menentukan suku ke- $n$ dan menentukan jumlah hingga pola ke- $n$ pada contoh pola yang diberikan. Hal ini mengindikasikan bahwa untuk menyelesaikan tugas generalisasi pola yang akan diberikan pada siswa perlu diperhatikan hal-hal apa saja yang pernah dipelajari sebelumnya. Hal ini juga menjadi salah satu alasan pemilihan subjek penelitian adalah kelas VII SMP.

Ketika menemui sebuah masalah, maka seseorang akan memikirkan solusi untuk memecahkan masalah. Salah satu penelitian Barbosa et al. (2012) mengungkapkan bahwa tugas eksplorasi pola dapat berkontribusi pada perkembangan kemampuan pemecahan masalah siswa melalui analisis kasus-kasus 
tertentu, mengorganisasi data, dan generalisasi. Barbosa et al, menggunakan istilah tugas eksplorasi pola karena tujuan utama penelitiannya yaitu melihat strategi generalisasi pola yang digunakan subjek-subjeknya. Hal ini mengindikasikan bahwa tugas generalisasi pola dapat melatih kemampuan pemecahan masalah siswa. Dalam memecahkan masalah, setiap siswa akan menggunakan strategi penyelesaian yang berbeda. Setiap siswa juga mempunyai karakteristik yang berbeda satu sama lain dalam melihat dan memproses sebuah informasi dari permasalahan yang mereka temui. Secara signifikan terdapat perbedaan antar individu dalam menyelesaikan masalah dan mengambil keputusan. Cara siswa merespons informasi berbeda satu dengan yang lain. Perbedaan antar siswa dalam menyusun dan mengolah informasi tersebut dikenal sebagai gaya kognitif.

Gaya kognitif yang konsisten dalam menggambarkan perilaku seseorang dan sering digunakan adalah gaya kognitif field dependent (FD) dan field independent (FI). Guisande, et al (2007) mengungkapkan gaya kognitif FD dan FI adalah salah satu gaya kognitif yang paling banyak dipelajari dari berbagai macam dimensi gaya kognitif pada literatur-literatur. Altun \& Cakan (2006) menyatakan bahwa seseorang digolongkan dalam gaya kognitif Fl jika cenderung bersifat analitis serta mendekati permasalahan dengan cara yang lebih analitis pula. Sebaliknya seseorang digolongkan dalam gaya kognitif FD jika cenderung mendekati permasalahan secara global dengan melihat suatu gambaran utuh dari konteks yang diberikan. Berkaitan dengan pola, Witkin (dalam Rahman, 2013) mengungkapkan bahwa seseorang memiliki gaya kognitif field independent cenderung memisahkan bagianbagian dari sejumlah pola dan menganalisis sesuai komponen yang mereka lihat. Lebih lanjut dijelaskan tentang seseorang yang memiliki gaya kognitif field dependent cenderung melihat pola secara keseluruhan dan tidak memisahkan menjadi bagian-bagian.

\section{Masalah}

Krulik dan Rudnick (1988) mendefinisikan masalah sebagai situasi yang memerlukan pemikiran dan perpaduan pengetahuan yang telah didapat sebelumnya untuk penyelesaian. Kantowskii (dalam Pehkonen, 2011) berpendapat bahwa suatu tugas dikatakan sebagai masalah jika solusinya mensyaratkan seseorang untuk menggabungkan pengetahuan yang telah diperoleh sebelumnya dengan cara yang baru (bagi individu tersebut). Sedangkan Polya (1973) membagi masalah matematika menjadi dua jenis, yaitu masalah menemukan (problem to find), dan masalah membuktikan (problem to prove).

\section{Pemecahan Masalah}

Polya (1973) menyatakan bahwa pemecahan masalah adalah suatu usaha untuk menemukan solusi dengan cara yang sesuai dan belum diketahui sebelumnya. Lebih lanjut, Polya (1981) juga mengungkapkan bahwa pemecahan masalah adalah upaya mencari jalan keluar dari suatu kesulitan, mencapai suatu tujuan yang tidak dengan segera dapat dicapai. Krulik dan Rudnick (1988) menyatakan bahwa pemecahan masalah adalah suatu usaha individu menggunakan pengetahuan yang diperoleh sebelumnya, keterampilan, dan pemahaman untuk menemukan solusi dari suatu masalah. Sedangkan NCSM (Pehkonen, 2011) menyatakan bahwa pemecahan masalah dapat diartikan sebagai suatu proses dimana data/ informasi yang telah diperoleh sebelumnya digunakan untuk menyelesaikan suatu situasi baru yang belum diketahui solusinya.

Krulik dan Rudnick (1988) berpendapat bahwa terdapat lima tahap dalam pemecahan masalah, yaitu: (1) membaca masalah (read), (2) mengeksplorasi (explore), (3) memilih strategi (select a strategy), (4) menyelesaikan masalah (solve), dan (5) memeriksa dan menyimpulkan (review and extand). Sedangkan Polya (1973) menjelaskan langkah-langkah pemecahan masalah dalam empat tahap yaitu memahami masalah (understanding the problem), menyusun rencana (devising a plan), melaksanakan rencana (carrying out the plan), dan memeriksa kembali (looking back).

Pola

Definisi pola telah banyak diungkapkan oleh beberapa peneliti. Salah satunya adalah pendapat Guerrero dan Rivera (dalam Tanişli dan Őzdaş, 2009) tentang pola yaitu aturan 
antara angota-anggota sebuah barisan objek matematika. Selanjutnya Birken dan Coon (2008) mendefinisikan pola sebagai pengaturan kata-kata, bilangan, atau bentuk-bentuk yang bisa dikenali. Sedangkan Mulligan dan Mitchelmore (2009) menyebutkan bahwa pola matematika dapat dideskripsikan sebagai keteraturan objek-objek yang dapat diprediksi, melibatkan numerik, spasial atau hubungan logis. Tim peneliti "MathGains" (2011) membagi pola menjadi pola berulang (repeating pattern) dan pola berkembang (growing pattern). Salah satu jenis pola berkembang yaitu pola berkembang linear. Dalam konteks pola bilangan, maka pola berkembang linear adalah pola berkembang dengan selisih tiap sukunya sama/konstan.

\section{Generalisasi Pola}

Kaput (1999) mendefinisikan generalisasi merupakan jangkauan dari penalaran dan komunikasi yang diperluas melampaui beberapa kasus yang fokusnya tidak lagi berada pada kasus itu sendiri melainkan pada pola, prosedur, struktur, dan hubungan diantara kasus-kasus tersebut. Dalam kaitannya dengan konteks pola, Beatty dan Bruce (2012) mendefinisikan generalisasi pola sebagai penentuan aturan yang memungkinkan untuk menjadi sebuah prediksi suku tertentu pada suatu barisan bilangan.

\section{Pemecahan Masalah Generalisasi Pola}

Pada penelitian ini, tugas generalisasi pola akan disajikan dalam tiga bentuk yang berbeda, yaitu: 1) generalisasi pola pada pola bilangan, 2) generalisasi pola pada pola gambar, dan 3) generalisasi pola pada masalah kontekstual yang masing-masing memuat soal untuk menentukan suku kecil, suku besar, dan suku ke- $n$. Suku kecil dibatasi maksimal sampai suku ke-10, sedangkan suku besar dibatasi minimal suku ke-11 dan maksimal suku ke-70. Sedangkan penentuan aturan umum atau suku- $n$ dilakukan untuk melihat siswa bagaimana menggunakan strategi generalisasi pola. Alasan pemilihan ini adalah di Indonesia pola bilangan dan pola pada gambar mulai diberikan pada tingkat SMP. Sedangkan pola pada masalah kontekstual juga memuat pola bilangan atau pola gambar.

Aktivitas generalisasi dalam penelitian ini mengacu pada tahapan pemecahan masalah yang mengacu pada langkah pemecahan masalah Polya, yaitu memahami masalah, merencanakan penyelesaian, melaksanakan rencana penyelesaian, dan memeriksa kembali penyelesaian. Sedangkan tugas generalisasi pola yang diberikan pada siswa juga telah diidentifikasi oleh Dindyal (2007) dengan empat tahap yang berhasil dalam aktivitas generalisasi yaitu tahap pemodelan langsung (direct modeling), identifikasi pola (pattern identification), uji (pembuktian) pola (prooftesting of the pattern), dan menentukan aturan untuk kasus umum (determining rule for general case). Adapun aspek indikator yang digunakan untuk melihat aktivitas generalisasi siswa dalam menyelesaikan tugas generalisasi pola adalah mengombinasikan tahap pemecahan masalah Polya dan tahap pada aktivitas generalisasi pola oleh Dindyal dapat dilihat pada Tabel 1.

Pada tahap melaksanakan rencana penyelesaian yaitu siswa menggunakan strategi generalisasi. Dalam tugas generalisasi pola,

Tabel 1. Tahap-Tahap pada Pemecahan Masalah Generalisasi Pola

\begin{tabular}{ll}
\hline \multicolumn{1}{c}{ Tahap } & \multicolumn{1}{c}{ Aspek Indikator } \\
\hline Memahami masalah & $\begin{array}{l}\text { Mengidentifikasi informasi yang diketahui dari soal; Mengidentifikasi apa yang } \\
\text { ditanyakan dari soal. }\end{array}$ \\
$\begin{array}{l}\text { Merencanakan } \\
\text { penyelesaian }\end{array}$ & $\begin{array}{l}\text { Mengenali pola dengan melihat hubungan di antara dua suku berurutan yang } \\
\text { diberikan; Merencanakan penyelesaian dengan memilih strategi generalisasi } \\
\text { yang akan dilakukan. }\end{array}$ \\
$\begin{array}{l}\text { Melaksanakan rencana } \\
\text { penyelesaian }\end{array}$ & $\begin{array}{l}\text { Menggunakan strategi generalisasi. } \\
\text { Memeriksa kembali } \\
\text { penyelesaian }\end{array}$ \\
\hline
\end{tabular}


Tabel 2. Strategi-strategi Generalisasi Pola yang Dikembangkan Barbosa et al. (2009)

\begin{tabular}{|c|c|c|}
\hline \multicolumn{2}{|c|}{ Strategi } & Penjelasan \\
\hline \multicolumn{2}{|l|}{ Counting } & $\begin{array}{l}\text { Menghitung/membuat model untuk menggambarkan situasi atau } \\
\text { membilang atribut apa saja yang diinginkan. }\end{array}$ \\
\hline \multirow{3}{*}{$\begin{array}{l}\text { Whole } \\
\text { Object }\end{array}$} & $\begin{array}{l}\text { No } \\
\text { adjustment }\end{array}$ & $\begin{array}{l}\text { Melihat satu suku pada barisan sebagai satu bagian dan menggunakan } \\
\text { perkalian dari bagian tersebut. }\end{array}$ \\
\hline & $\begin{array}{l}\text { Numeric } \\
\text { adjustment }\end{array}$ & $\begin{array}{l}\text { Melihat satu suku pada barisan sebagai satu bagian dan menggunakan } \\
\text { perkalian dari bagian tersebut. Penyesuaian akhir dilakukan sesuai sifat-sifat } \\
\text { numerik. }\end{array}$ \\
\hline & $\begin{array}{l}\text { Visual } \\
\text { adjustment }\end{array}$ & $\begin{array}{l}\text { Melihat satu suku pada barisan sebagai satu bagian dan menggunakan } \\
\text { perkalian dari bagian tersebut. Penyesuaian akhir dilakukan sesuai konteks } \\
\text { permasalahan yang tersaji. }\end{array}$ \\
\hline \multirow{3}{*}{ Difference } & Recursive & $\begin{array}{l}\text { Memanjangkan barisan menggunakan beda yang sama dari suku-suku } \\
\text { sebelumnya. }\end{array}$ \\
\hline & $\begin{array}{l}\text { Rate-no } \\
\text { adjustment }\end{array}$ & $\begin{array}{l}\text { Menggunakan beda yang sama sebagai faktor perkalian tanpa melanjutkan } \\
\text { dengan penyesuaian akhir. }\end{array}$ \\
\hline & $\begin{array}{l}\text { Rate- } \\
\text { adjusment }\end{array}$ & $\begin{array}{l}\text { Menggunakan beda yang sama sebagai faktor perkalian dan dilanjutkan } \\
\text { dengan penyesuaian akhir. }\end{array}$ \\
\hline \multicolumn{2}{|l|}{ Explicit } & $\begin{array}{l}\text { Menemukan aturan (pola) sesuai konteks permasalahan yang tersaji dan } \\
\text { memungkinkan untuk menentukan sebarang suku. }\end{array}$ \\
\hline \multicolumn{2}{|c|}{ Guess and Check } & $\begin{array}{l}\text { Memprediksi atau menebak aturan pola dengan mempertimbangkan } \\
\text { aturan tersebut digunakan. }\end{array}$ \\
\hline
\end{tabular}

siswa akan diminta menentukan suku-suku tertentu pada sebuah pola yang selanjutnya akan diminta menuliskan aturan yang memungkinkan untuk menentukan sebarang suku. Setiap siswa akan menggunakan strategi yang berbeda-beda dalam menyelesaikan tugas tersebut (Barbosa et al., 2009). Klasifikasi strategi generalisasi pola dibatasi pada caracara yang dilakukan siswa dalam menentukan suku-suku tertentu saja.

\section{Gaya Kognitif}

Tennant (dalam Liu dan Ginther, 1999) mendefinisikan gaya kognitif sebagai karakteristik dan cara yang konsisten dari individu dalam mengorganisasi dan memproses informasi. Sedangkan Liu dan Ginther (1999) menyatakan bahwa gaya kognitif menunjuk pada kekonsistenan dan kecenderungan karakteristik individu dalam merasa, mengingat, mengorganisasi, memproses, berpikir, dan memecahkan masalah.

Witkin (dalam Danili dan Reid, 2006) mengemukakan bahwa gaya kognitif FI dan FD dipandang sebagai salah satu variabel penentu pada kemampuan seseorang dalam memecahkan masalah. Berdasarkan paparan tersebut, peneliti tertarik untuk fokus dengan gaya kognitif field independent dan field depen- dent dalam penelitian. Gaya kognitif FI dan FD pertama kali diusulkan oleh Witkin. Witkin dan Goodenough (dalam Danili dan Reid, 2006) mendefinisikan bahwa seseorang dengan gaya kognitif field independent (FI) adalah seseorang yang dengan mudah dapat "bebas" dari persepsi terorganisir dan segera dapat memisahkan suatu bagian dari kesatuannya. Sedangkan seseorang dengan gaya kognitif field dependent (FD) adalah seseorang yang kurang atau tidak bisa memisahkan suatu bagian dari suatu kesatuan dan cenderung segera menerima bagian yang dominan.

\section{METODE}

Jenis penelitian ini adalah penelitian kualitatif yang menghasilkan data deskriptif. Penelitian ini mengambil subjek yaitu 2 siswa kelas VII SMP yang masing-masing memiliki gaya kognitif FI dan FD. Dasar dari pemilihan subjek adalah pernyataan pada penelitian Stacey dan Orton\&Orton (dalam Barbosa, 2012) yang menyatakan bahwa aktivitas generalisasi pola menarik dan menantang untuk siswa usia 8 tahun sampai 13 tahun atau setara dengan pendidikan Indonesia pada tingkat kelas III SD sampai VIII SMP. Pemilihan subjek dimulai dengan memberikan Group Embedded Figure Test (GEFT). Hasil tes tersebut mengelompokkan siswa dengan gaya kognitif field independent 
dan field dependent. Selanjutnya calon subjek diberikan tes kemampuan matematika (TKM) agar subjek yang terpilih mempunyai kemampuan matematika setara. Selain itu calon subjek berjenis kelamin sama yaitu perempuan untuk meminimalisir pengaruh jenis kelamin terhadap pemecahan masalah generalisasi pola.

Instrumen yang digunakan dalam penelitian ini ada dua yaitu instrumen utama dan instrumen pendukung. Instrumen utama yaitu peneliti sendiri, sedangkan instrumen pendukung meliputi Group Embedded Figure Test (GEFT), tes kemampuan matematika (TKM), tugas generalisasi pola (TGP), dan pedoman wawancara. Terdapat tiga macam metode pengumpulan data dalam penelitian ini, yaitu metode tes meliputi Group Embedded Figure Test (GEFT), dan Tes Kemampuan Matematika (TKM), metode tugas menggunakan Tugas Generalisasi Pola (TGP), dan metode wawancara. Sedangkan teknik analisis data meliputi analisis hasil GEFT, dan analisis hasil TKM, TGP, dan wawancara. Analisis data dalam penelitian ini yaitu mereduksi, menyajikan, dan menarik simpulan data.

\section{HASIL PENELITIAN}

\section{Tugas Generalisasi Pola pada Pola Bilangan}

Tugas generalisasi pola disajikan dalam bentuk uraian meliputi: 1) tugas generalisasi pola pada pola bilangan, 2) tugas generalisasi pola pada pola gambar, dan 3) tugas generalisasi pola berbentuk masalah kontekstual. TGP dirancang sedemikian hingga siswa diminta untuk menentukan suku kecil, suku besar dan suku ke- $n$. Suku kecil dibatasi maksimal sampai suku ke-10, sedangkan suku besar dibatasi minimal suku ke-11 dan maksimal suku ke-70. Berikut adalah tugas generalisasi pola pada pola bilangan.

Diketahui pola bilangan

$$
6,2,2,6 \ldots
$$

Misal bilangan pertama pada barisan tersebut disebut suku pertama, bilangan kedua disel suku kedua, bilangan ketiga disebut suku ketiga, dan seterusnya. Jelaskan bagaima caramu

a. Menentukan suku ke 10 pada barisan bilangan tersebut!

b. Menentukan suku ke -40 pada barisan bilangan tersebut!

c. Menentukan suku ke $n$ (untuk $n$ adalah sebarang bilangan asli). Jelaskan alasanmu!

\section{Pembahasan Pemecahan Masalah Generalisasi Pola Subjek Field Inde- pendent (SFI)}

Tahap memahami masalah pada tugas generalisasi pola berbentuk pola bilangan yang diberikan, SFI memahami masalah dengan mengidentifikasi informasi yang diketahui dan apa yang ditanyakan pada soal dengan membaca soal. SFI mengidentifikasi kembali informasi yang diketahui dan yang ditanyakan pada soal dan menyimbolkannya dengan tepat. Pada saat menuliskan data yang diketahui dan yang ditanyakan, SFI cenderung menggunakan notasi matematika dan menggunakan bahasanya sendiri. Hal ini sesuai dengan pernyataan Kheirzaden \& Kassaian (2011) yaitu ketika bidangnya tidak diorganisir secara jelas, individu FI relatif cenderung menerapkan struktur mereka sendiri, sedangkan individu FD menerima seperti apa adanya.

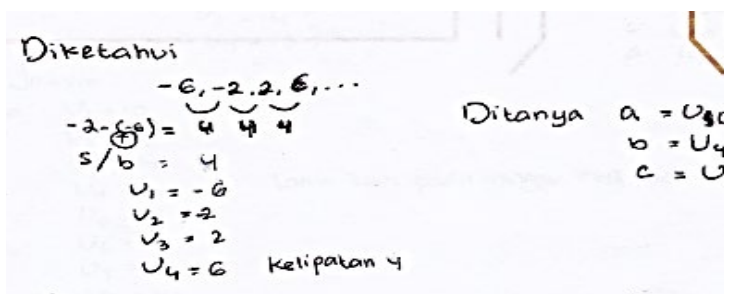

Tahap merencanakan penyelesaian diawali SFI dengan mengenali hubungan antar dua suku berurutan dengan menghitung selisih antara bilangan kedua dengan bilangan pertama dan melihat bahwa antar dua suku berurutan pada pola bilangan mempunyai aturan yang sama. SFI mampu menentukan hubungan antar suku dan membuat kesimpulan bahwa aturan pada pola bilangan adalah sama. SFI menggunakan rumus beda pola bilangan. Untuk menentukan suku kecil, SFI merencanakan penyelesaian dengan membilang suku-suku pada pola bilangan hingga pada suku yang diminta. Untuk menentukan suku besar, SFI merencanakan penyelesaian dengan menggunakan kelipatan suku tertentu kemudian memperhatikan beda pada setiap kelipatan sukunya. Sedangkan untuk menentukan aturan umum atau suku ke- $n$, SFI berencana menyelesaikan dengan memperhatikan beda/selisih dan bilangan-bilangan yang diketahui pada pola bilangan. Dari jawa- 
ban SFI terlihat bahwa dalam merencanakan penyelesaian masalah, SFI cenderung lebih dipengaruhi isyarat dari dalam dirinya sendiri, karena memikirkan mencari besar beda terlebih dahulu dan memperhatikan bilangan-bilangan yang diketahui pada pola bilangan untuk mencari suku ke- $n$. Hal ini sejalan dengan yang dikemukakan Amstrong, et al. (2011) yaitu individu $\mathrm{Fl}$ mengadopsi pendekatan impersonal untuk pemecahan masalah, sedangkan individu FD mengadopsi pendekatan interpersonal untuk memecahkan masalah.

Tahap melaksanakan rencana penyelesaian, diawali SFI dengan menentukan beda diantara dua suku berurutan dan melihat bahwa beda tersebut adalah konstan. Untuk menentukan suku kecil, SFI membilang suku-suku pada pola bilangan dengan menggunakan beda yang didapat sampai pada suku tertentu. Strategi yang dilakukan SFI adalah strategi counting. Untuk menentukan suku besar, SFI awalnya membilang suku-suku pada pola bilangan menggunakan beda yang didapat sampai pada suku tertentu. SFI melihat bahwa tiap kelipatan suku tertentu mempunyai beda konstan yang "baru". Sehingga SFI menggunakan setiap kelipatan suku kemudian memperhatikan beda antar kelipatan suku tersebut hingga menemukan suku yang diminta. SFI menemukan aturan yang sesuai konteks permasalahan yang tersaji dan memungkinkan untuk menentukan sebarang suku. Strategi yang dilakukan SFI adalah strategi explicit. Hal ini sejalan dengan penelitian Lannin (2006) yang menyarankan siswa menggunakan penalaran untuk strategi explicit untuk menentukan suku besar. Untuk menentukan aturan umum atau suku ke- $n$, SFI menjadikan beda pada pola bilangan menjadi faktor pengali dengan suku tertentu. Kemudian SFI mencoba mengalikan beberapa nilai input (relatif kecil) dengan beda yang didapat dan dan menyadari terdapat selisih yang konstan untuk setiap hasil perkaliannya. SFI menyimpulkan bahwa untuk mencari suku dengan nilai input sebarang diperoleh dari beda dikali dengan nilai input kemudian dikurangi atau ditambah dengan selisih yang didapat dan melanjutkan dengan menguji kebenaran jawabannya dengan mencoba memisalkan $n$ dengan beberapa bilangan yang cukup kecil sehingga hasilnya dapat dilihat secara langsung. Strategi yang dilakukan SFI adalah strategi difference-rate adjustment.

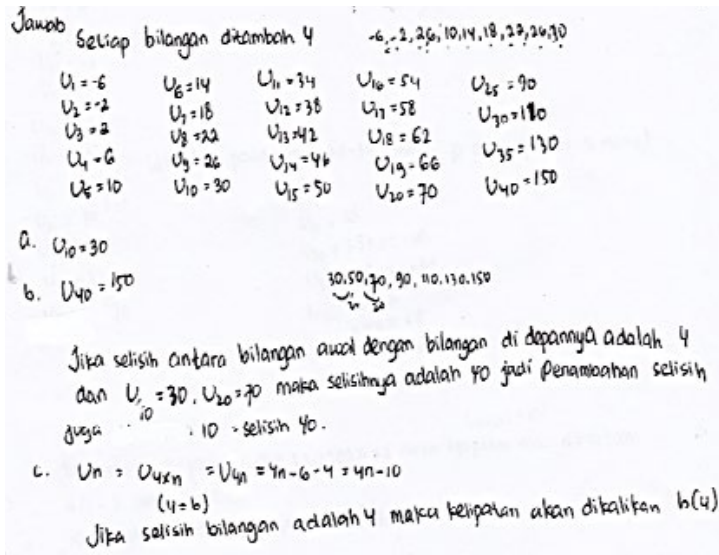

\section{Gambar 1. Hasil pekerjaan siswa SFI}

Setelah mengerjakan TGP berbentuk pola bilangan suku kecil, SFI memeriksa jawaban dengan melihat kembali perhitungan sesuai selisih/beda pada pola bilangan dan tidak berusaha menemukan cara lain untuk menyelesaikan soal nomor (1a). Setelah mengerjakan TGP berbentuk pola bilangan suku besar, SFI memeriksa jawaban dengan menghitung kembali perhitungan sesuai selisih/beda pada pola bilangan dan menemukan cara lain untuk menyelesaikan soal nomor (1b) yaitu membilang suku-suku pada pola bilangan, tetapi cara tersebut tidak dilakukan karena memakan waktu yang lama. Setelah mengerjakan TGP berbentuk pola bilangan suku ke- $n, \mathrm{SFI}$ memeriksa kembali hasil dengan mensubstitusi bilangan-bilangan relatif kecil ke jawaban yang sudah diperolehnya. SFI tidak berusaha menemukan cara lain untuk menyelesaikan TGP 1 berbentuk pola bilangan pada suku ke$n$.

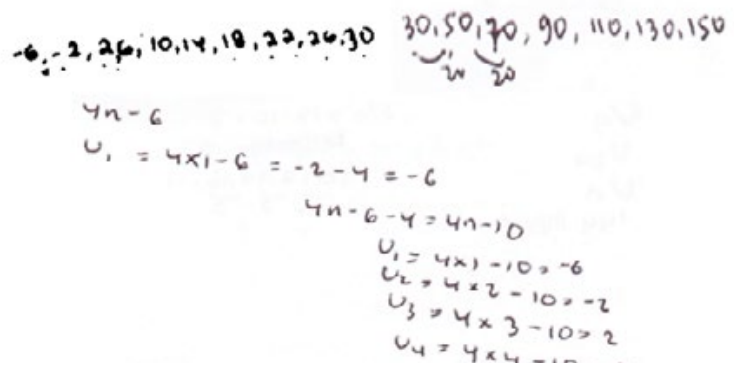

Gambar 2. Hasil pekerjaan siswa SFI 


\section{Pembahasan Pemecahan Masalah Generalisasi Pola Subjek Field De- pendent (SFD)}

SFD memahami masalah pada tugas generalisasi pola berbentuk pola bilangan yang diberikan dengan mengidentifikasi informasi yang diketahui dan apa yang ditanyakan pada soal dengan membaca soal. SFD mengidentifikasi kembali informasi yang diketahui dan yang ditanyakan pada soal kemudian menyimbolkannya.

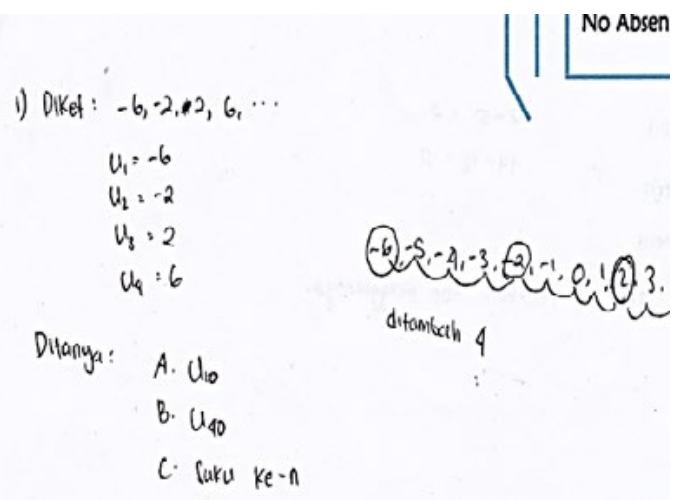

Gambar 3. Hasil pekerjaan siswa SFD

SFD mengenali hubungan antar dua suku berurutan dengan menghitung selisih antara bilangan kedua dengan bilangan pertama dan melihat bahwa antar dua suku berurutan pada pola bilangan mempunyai aturan yang sama. Saat menentukan hubungan antar dua suku berurutan, SFD menghitung satu-persatu selisih antara bilangan kedua dengan bilangan pertama. Untuk menentukan suku kecil, SFD merencanakan penyelesaian dengan membilang satu persatu hingga suku yang dimaksud. Untuk suku besar, SFD merencanakan penyelesaian dengan membilang satu persatu hingga suku yang dimaksud. Untuk menentukan aturan umum atau suku ke- $n$, SFD merencanakan penyelesaian soal adalah dengan memperhatikan beda/selisish pada pola bilangan yang akan dibuat kelipatan.

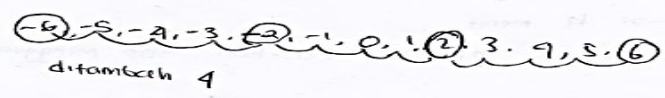

Gambar 4. Hasil pekerjaan siswa SFD di barisan bilangan
Untuk menentukan suku kecil dan suku besar pada semua jenis TGP yang diberikan, SFD memperpanjang pola bilangan yang tersedia hingga didapat suku tertentu. Strategi SFD adalah strategi recursive. Dindyal (2007) menjelaskan bahwa siswa cenderung melakukan pemodelan langsung dengan menghitung, menggambar, menuliskan secara sistematis sebagai langkah awal dalam melakukan generalisasi. Beberapa peneliti (Stacey, 1989; Lannin, 2006; Swafford dan Langrall, 2000 dalam Dindyal, 2007) mendapati bahwa salah satu alasan siswa menggunakan strategi recursive dalam menentukan suku-suku tertentu adalah mereka mampu menemukan pola-pola numerik dalam permasalahan yang diberikan. Untuk menentukan aturan umum atau suku ke-n pada semua TGP yang diberikan, SFD menentukan beda pola bilangan dan menjadikannya sebagai faktor pengali dengan suku tertentu dan menyimpulkan bahwa untuk mencari suku dengan nilai input sebarang diperoleh dari beda dikali dengan nilai input. Strategi yang digunakan SFD adalah strategi difference rate-no adjustment.

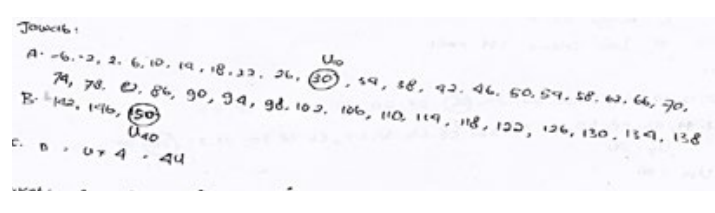

Gambar 5. Hasil Pekerjaan siswa SFD pada suku ke-n

Setelah mengerjakan TGP berbentuk pola bilangan pada suku kecil, SFD mengecek jawaban dengan meneliti kembali perhitungan yang telah dilakukan dan tidak berusaha menemukan cara lain untuk menyelesaikan soal. Setelah mengerjakan TGP berbentuk pola bilangan pada suku besar, SFD mengecek jawaban dengan meneliti kembali perhitungan yang telah dilakukan dan tidak berusaha menemukan cara lain untuk menyelesaikan soal. Setelah mengerjakan TGP berbentuk pola bilangan pada suku ke-n, SFD tidak mengecek kembali jawaban yang diperoleh karena SFD tidak tahu bagaimana jawaban yang benar dan tidak berusaha menemukan cara lain untuk menyelesaikan soal. 


\section{SIMPULAN}

Tahap memahami masalah dimulai siswa field independent dengan mengidentifikasi informasi yang diketahui dan apa yang ditanyakan pada soal dengan membaca soal dan menyimbolkannya. Tahap merencanakan penyelesaian diawali siswa dengan mengenali hubungan antar dua suku berurutan dengan menghitung selisih antara bilangan kedua dengan bilangan pertama dan melihat bahwa antar dua suku berurutan pada barisan bilangan mempunyai aturan yang sama. Untuk menentukan suku kecil, siswa merencanakan penyelesaian dengan membilang suku-suku pada barisan bilangan hingga pada suku yang diminta. Untuk menentukan suku besar, siswa merencanakan menggunakan kelipatan suku tertentu kemudian memperhatikan beda pada setiap kelipatan sukunya. Sedangkan untuk menentukan aturan umum atau suku ke- $n$, siswa berencana menyelesaikan dengan memperhatikan beda/ selisih dan bilangan-bilangan yang diketahui pada barisan bilangan. Tahap melaksanakan rencana penyelesaian, diawali siswa dengan menentukan beda diantara dua suku berurutan dan melihat bahwa beda tersebut adalah konstan. Untuk menentukan suku kecil, siswa membilang suku-suku pada barisan bilangan dengan menggunakan beda yang didapat sampai pada suku tertentu. Strategi yang dilakukan siswa adalah strategi counting. Untuk menentukan suku besar, siswa menggunakan kelipatan suku tertentu dan memperhatikan beda konstan yang "baru". Strategi yang dilakukan siswa adalah strategi explicit. Untuk menentukan aturan umum atau suku ke- $n$, siswa menjadikan beda barisan bilangan menjadi faktor pengali dengan suku tertentu kemudian melakukan penyesuaian akhir dan menyimpulkan bahwa untuk mencari suku dengan nilai input sebarang diperoleh dari beda dikali dengan nilai input kemudian dikurangi atau ditambah dengan selisih yang didapat Strategi yang dilakukan siswa adalah strategi difference-rate adjustment. Setelah mengerjakan TGP suku kecil, siswa memeriksa jawaban dengan melihat kembali perhitungan sesuai selisih/beda pada barisan bilangan dan tidak berusaha menemukan cara lain untuk menyelesaikan soal nomor (1a). Setelah mengerjakan TGP suku besar, siswa memeriksa jawaban dengan menghitung kembali perhitungan sesuai selisih/beda pada barisan bilangan dan menemukan cara lain untuk menyelesaikan soal nomor (1b) yaitu membilang suku-suku pada barisan bilangan, tetapi cara tersebut tidak dilakukan karena memakan waktu yang lama. Setelah mengerjakan TGP suku ke-n, siswa memeriksa jawabannya dengan mensubstitusi bilangan-bilangan relatif kecil ke jawaban yang sudah diperoleh dan tidak berusaha menemukan cara lain untuk menyelesaikan TGP pada suku ke-n.

Tahap memahami masalah diawali siswa field dependent dengan mengidentifikasi informasi yang diketahui dan apa yang ditanyakan pada soal dengan membaca soal. Siswa mengidentifikasi kembali informasi yang diketahui dan yang ditanyakan pada soal dan menyimbolkannya. Tahap merencanakan penyelesaian diawali siswa dengan mengenali hubungan antar dua suku berurutan dengan menghitung selisih antara bilangan kedua dengan bilangan pertama. Untuk menentukan suku kecil, siswa menentukan rencana penyelesaian soal dengan membilang satu persatu hingga suku yang dimaksud. Untuk suku besar, siswa merencanakan penyelesaian adalah dengan membilang satu persatu hingga suku yang dimaksud. Untuk menentukan aturan umum atau suku ke-n, siswa merencanakan penyelesaian adalah dengan memperhatikan beda/selisish pada barisan bilangan yang akan dibuat kelipatan. Tahap melaksanakan rencana penyelesaian untuk suku kecil yaitu siswa memperpanjang barisan bilangan yang tersedia hingga didapat suku tertentu. Strategi yang siswa adalah strategi recursive. Untuk menentukan suku besar, siswa juga memperpanjang barisan bilangan sampai suku tertentu. Strategi yang digunakan siswa adalah strategi recursive. Untuk menentukan aturan umum atau suku ke- $n$, siswa menentukan beda barisan bilangan dan menjadikannya sebagai faktor pengali dengan suku tertentu tanpa melakukan penyesuaian akhir. Siswa menyimpulkan bahwa untuk mencari suku dengan nilai input sebarang diperoleh dari beda dikali dengan nilai input. Strategi yang digunakan siswa adalah strategi difference rate-no adjustment. Tahap memeriksa kembali penyelesaian suku kecil, siswa mengecek jawaban dengan meneliti kembali perhitungan yang telah dilakukan dan 
tidak berusaha menemukan cara lain untuk menyelesaikan soal. Pada suku besar, siswa mengecek jawaban dengan meneliti kembali perhitungan yang telah dilakukan dan tidak berusaha menemukan cara lain untuk menyelesaikan soal. Pada suku ke- $n$, siswa tidak mengecek kembali jawaban yang diperoleh karena siswa tidak tahu bagaimana jawaban yang benar dan tidak berusaha menemukan cara lain untuk menyelesaikan soal.

Berdasarkan hasil penelitian dan pembahasan yang telah dipaparkan pada bab sebelumnya, maka peneliti memberikan saran kepada peneliti lain yang melakukan penelitian serupa diharapkan untuk meminimalisir kelemahan yang ada pada penelitian ini, yakni sebaiknya tugas generalisasi pola (TGP) dirancang sedemikian hingga siswa diminta untuk menentukan beberapa suku kecil dan suku besar dengan jarak yang cukup besar. Hal ini akan membuat peneliti bisa melihat apakah siswa dalam menentukan suku-suku kecil akan melakukan pemecahan masalah generalisasi yang sama dengan suku-suku besar. Misalnya suku kecil dibatasi sampai suku ke-10, dan suku besar dibatasi sampai suku ke-100. Dengan demikian diharapkan peneliti dapat melihat apakah dengan jarak yang cukup besar tersebut membuat siswa melakukan pemecahan masalah dan menentukan strategi yang sama untuk menentukan suku. TGP dalam penelitian ini hanya meminta siswa menentukan satu suku kecil dan satu suku besar. Sehingga peneliti belum dapat melihat apakah siswa melakukan pemecahan masalah yang sama dalam menentukan semua suku, termasuk suku kecil atau besar. Sedangkan saran kepada guru matematika diharapkan dapat merancang strategi pembelajaran yang tepat dalam pengajaran pola bilangan sehingga siswa dengan gaya kognitif field independent dan field dependent. Diharapkan siswa memiliki kemampuan pemecahan masalah yang baik dan juga guru diharapkan melakukan evaluasi terhadap proses dan cara siswa memecahkan masalah pola bilangan khususnya generalisasi pola beserta pemberian scaffoldingnya sehingga siswa dapat memecahkan masalah dengan baik dan benar, misalnya mengajarkan pada siswa bagaimana menye- lesaikan tugas generalisasi pola yang meminta menentukan beberapa suku kecil dan suku besar yang beragam.

\section{DAFTAR PUSTAKA}

Altun, A. \& Cakan, M. (2006). Undergraduate Students' Academic Achievement, Field Dependent/Independent Cognitive Styles and Attitude toward Computers. Educational Technology \& Society. 9(1), 289-297.

Barbosa, A,. Vale, I., \& Palhares, P. (2009). Exploring Generalization with Visual Pattern: Tasks Developed with Pre-algebra Students. Comunicação Apresentada no International Meeting on Patterns. 4, 42-52.

Barbosa, A, Vale, I., \& Palhares, P. (2012). Pattern Tasks: Thinking Processes Used By 6th Grade Studentd. Revista Latinoamericana de Investigación en Matemática Educativa.15(3), 273-293.

Birken, M. \& Coon, A. C. (2008). Discovering Patterns in Mathematics and Poetry. Rochester, New York.

Dindyal, J. (2007). High School Students' Use of Patterns and Generalisation. Proceedings of the 3oth Annual Conference of the Mathematics Education Research Group of Australasia. 1, 236-245.

Guisande, A. M., dkk.(2007). Field Dependence-Independence (FDI) Cognitive Style: An Analysis of Attentional Functioning. 19, 572-577.

Kaput, J. J. (1999). Teaching and Learning a New Algebra With Understanding. University of Massachusetts-Dartmouth. (Online).

Krulik, S \& Rudnick, J. A. (1988). Problem Solving: A Handbook fo Elementary School Teachers. Needham Heights: Allyn \& Bacon.

Kheirzaden, S. \& Kassaian, Z. (2011). Field dependence/ independence as a Factor Affecting Performance on Listening Comprehension Sub-skills: the Case of Iranian EFL Learners. Journal of Language Theaching and Research, 2(1), 188-195.

Lannin, J. K., Barker, D. D., \& Townsend, B. E. (2006). Recursive and explicit rules: How can we build student algebraic understanding?. The Journal of Mathematical Behavior, 25(4), 299-317.

Liv, Y. \& Ginther, D. (1999). Cognitive Style and Distance Education. Online Journal of Distance Learning Administration. 2(3).

Pehkonen, E. (2011). "Problem Solving in Mathematics Education in Finland". Different Conceptions of the Mathematical Knowledge Needed for Teaching and How it can be Acquired, and its Relation to Pedagogical Knowledge. Pp. 1-5.

Polya. (1973). How to Solve It : a New Aspect of Mathematical Method. USA: Princeton University Press.

Rahman, A. (2013). The Profile of Students' Mathematical Problem Posing Based on Their Cognitive Styles. Indian Streams Research Journal. ISSN 2230-7850, 3(7).

Tanişli, D. \& Ozdaş, A. (2009). The Strategies of Using the Generalizing Patterns of the Primary School $5^{\text {th }}$ Grade Students. Educational Sciences: Theory \& Practice. 9(3), 1485-1497.

Tim Peneliti "MathGains". (2011). Patterning to Algebra Lessons K-3. 